\title{
Implications of the Ecosystem-Based Approach to Wetlands Management on the Kenyan Coast
}

\author{
Collins Odote
}

The evolution of the concept of the ecosystem approach has heralded innovations in the thinking on, and rules for, the management of natural resources. As it is understood today, the ecosystem approach emerged from the requirements of the Convention on Biological Diversity ( С ВD $)^{1}$ and its implementation has been intertwined with that of the $\mathrm{CBD}$. The approach requires integration in the management of the environment and natural resources and eschews an approach which is purely sectoral. Wetlands provide an important lens through which to assess the application of the ecosystem approach to the management of coastal ecosystems. Together with forests, wetlands are the most important, yet most seriously threatened, ecosystems in the world..$^{2}$ Indeed, the degradation and loss of wetlands is occurring more rapidly than that of forests or any other ecosystem. ${ }^{3}$ The reason could be that forests have always been viewed as a useful ecosystem, providing the source of trees and related products and serving important functions in society. ${ }^{4}$ In contrast, the utility of wetlands to

1 United Nations Conference on Environment and Development: Convention on Biological Diversity (1992) 31:4 ILM 818. Also available at <https://www.cbd.int/doc/legal/cbd-en.pdf> accessed on 17 January 2018.

2 See Ramsar Convention Bureau, Wetlands and Biological Diversity: Cooperation between the Convention on Wetlands of International Importance and the Convention on Biological Diversity (Paper distributed to Delegates to the Third Meeting of the Conference of the Parties to the Convention on Biological Diversity, Buenos Aires, Argentina, 4-15 November, 1996). On file with author.

3 The Millennium Ecosystem Assessment points out that wetlands are the ecosystem that is degraded at the fastest rate. See World Resources Institute, Millennium Ecosystem Assessment: Ecosystems and Human Well-Being: Wetlands and Water, 2005. Available from <http:// www.millenniumassessment.org/documents/document.358.aspx.pdf> accessed 13 June 2016.

4 The comparison and differences between wetlands and forests is beyond the scope of this study. So is an exhaustive discussion of forest management and uses. For relevant literature on forest management in Kenya see, for example, Phoebe Okowa-Bennum and Albert M Mwangi, 'Land Tenure and Forest Resource Management' in Calestous Juma and JB Ojwang

(C) COLLINS ODOTE, 2019 | DOI:10.1163/9789004389984_014

This is an open access chapter distributed under the terms of the prevailing CC-BY-NC License at the time of publication. 
society has not always been accepted or appreciated. Indeed, historically, wetlands were viewed as useless areas, ${ }^{5}$ the utility of which required their conversion to more productive uses such as agriculture. This resulted in wetlands being referred to in certain quarters as 'wastelands' ${ }^{6}$

Part of the reason why the importance of wetlands was not appreciated, and efforts spent only in their conversion to other uses, was the failure to accurately assess and value their economic utility. Decision-makers, developers and land-use planners have long perceived little economic benefit to be gained from conserving wetlands and few economic costs have been attached to their degradation. ${ }^{7}$ However, over time, the utility and importance of wetlands have been understood, and the international community has responded by making efforts for their conservation. ${ }^{8}$ Nevertheless, despite developments in the appreciation and valuation of the importance of wetlands and the need for their conservation, they still continue to be degraded and/or lost. Whilst certain pressures on wetlands arise from natural causes (such as droughts which affect community migration patterns), it is human activities that have significantly altered the rate and nature of wetlands change. ${ }^{9}$ Even today, the rate

(eds), In Land We Trust: Environment, Private Property and Constitutional Development (Initiative Publishers and Zen Books 1996) 175-197; Francis DP Situma, 'Forestry Law and the Environment in Kenya' in CO Okidi and others (eds), Environmental Governance in Kenya: Implementing the Framework Law (East African Educational Publishers Ltd, Nairobi, 2008) 235-259.

5 See GVT Mathews, The Ramsar Convention on Wetlands: Its History and Development (Ramsar Convention Bureau, 1993) 6, discussing general perceptions of wetlands as waste areas, not fit for any use.

6 See Wetlands are not Dangerous Swamps; They're Worth Saving, Reuters Library Report, May 31, 1990 (BC Cycle) which reports that historically most people considered wetlands to be nothing more than swamps and wastelands, the breeding grounds for insects and diseases. See also Roy C. Gardner, 'Banking on Entrepreneurs: Wetlands Mitigation Banking and Takings' (1996) 81 Iowa Law Review 529 which points out that at one time wetlands were considered little more than mosquito-breeding nuisances.

7 L Emerton, 'The Economic Value of Africa's Wetlands' in ML Thieme (ed), Freshwater Ecoregions of Africa and Madagascar: A Conservation Assessment (World Wildlife Fund, 2005) 11-18, 11; BD Ratner and others, Undervalued and Overlooked: Sustaining Rural Livelihoods Through Better Governance of Wetlands, World Fish Centre Studies and Review No 28 (World Fish Centre, 2004), 7 .

8 See GVT Mathews ( $n_{5}$ ), pointing out that the international effort to demonstrate the importance of wetlands started with a campaign in North America in the 1930's. This was a result that contrary to earlier opinion, wetlands are useful ecosystems, with a wide range of benefits to the society.

9 C Shine and C de Klemm, Water and the Law: Using Law to Advance Wetland Conservation and Wise Use (IUCN and Cambridge, 1999), 13. 
and scale of wetlands loss and/or degradation ${ }^{10}$ has continued to increase. ${ }^{11}$ Wetlands, however, are amongst the most precious natural resources on earth ${ }^{12}$ and the most productive and valuable ecosystems in the world. ${ }^{13}$ They have useful attributes and perform important functions for humanity. In terms of functions, wetlands play a key role in hydrological balance. They act as a storage of water supply and regulate the water table through the maintenance and recharge of surface and underground water, supply; discharge of groundwater, and storage of floodwaters in flood plains. Other functions include water purification, control of soil erosion and climate stability. ${ }^{14}$

Wetlands also serve as habitat for many species. They provide an important reservoir of genetic material and are also a source of rich cultural heritage. In Kenya, as elsewhere, wetlands support livelihoods both directly and indirectly through supporting necessary ecological functions, such as provision of water, waste water treatment, maintenance of hydrological cycles, and prevention of storm damage and erosion. In some places they also serve unique cultural functions. The Millennium Ecosystem Assessment carried out between 2002 and 2005 remains the most comprehensive account to date of the state of the world's ecosystems and the required strategies for their conservation and sustainable use..$^{15}$ The report is famous for the linkages it demonstrated between

10 Wetland loss refers to the conversion of wetland area to a non-wetland area due to human activity, while degradation is the impairment of wetlands functions due to human activity without actual and total loss of the wetland area. For a discussion of these see Clare Shine and Cyrille de Klemm (ibid.) 13-23 and Roy C. Gardner, 'Rehabilitating Nature: A Comparative Review of Legal mechanisms That encourage Wetland Restoration Efforts' (2003) 52(3) The Catholic University Law Review 573.

11 Roy C. Gardner (ibid) 573-574 reports that throughout the world more than half of the world wetlands have disappeared with two-thirds of all European wetlands having disappeared since 1900 .

12 Ramsar Convention Bureau, 'Wetlands and Biological Diversity: Cooperation Between the Convention on Wetlands of International Importance especially as Waterfowl Habitat (Ramsar, Iran, 1971) and the Convention on Biological Diversity.' (1996, UNEP/CBD/Cop/3/ Inf. 21). On file with author.

13 See H Babcock, 'Federal Wetlands Regulatory Policy: Up to its Ears in Alligators' (1991) 8 Pace Environmental Law Review 307, 309.

14 The Ramsar Secretariat prepared a series of Fact Sheets in 2001 that summarized the key functions of wetlands as Flood control; Groundwater replenishment; Shoreline stabilisation and storm protection Sediment and nutrient retention and export; Water purification; Reservoirs of biodiversity; Wetland products; Cultural values; Recreation \& tourism; Climate change mitigation and adaptation. <http://archive.ramsar.org/pdf/info/ services_oo_e.pdf> accessed on 11 March 2018.

15 See Millennium Ecosystem Assessment, Ecosystems and Human Well-being: Synthesis (2005), available at <https://www.millenniumassessment.org/documents/document.356 .aspx.pdf $>$ accessed on 24 March 2018. 
ecosystems and human well-being through what it called ecosystem services, which it categorised into provisioning services, regulating services, social services and supporting services. ${ }^{16}$ Several thematic reports were also prepared in association with the Assessment, one of which focused on marine and coastal ecosystems. ${ }^{17}$ That report ${ }^{18}$ highlighted the importance of marine and coastal ecosystems, stating that the services they provide include supply of food, fuel wood, energy resources, natural products, and bioprospecting, shoreline stabilization, flood prevention, storm protection, climate regulation, hydrological services, nutrient regulation, carbon sequestration, detoxification of polluted waters, waste disposal, culture, tourism, and recreation, habitat provision, nutrient cycling, primary productivity, and soil formation. ${ }^{19}$

Governance of oceans and coasts is best understood as the process for policy making by competent institutions in a system of negotiation between nested governmental institutions at several levels (international, national, regional and local), on the one hand, and market parties and civil society organizations on the other. ${ }^{20}$ Only an integrated approach can help resolve the governance challenges of the oceans and the coast which:

for the most part, have been related to the intensifying nature of human interactions with the oceans and coasts and the inability of governance institutions to adapt. Governance processes have in the past primarily focused on regulating individual sectors, ignoring interactions between sectors and ocean ecosystems. While governance effectiveness varies, based on institutional architecture, often specific to a given place, sociopolitical context, legal and policy regime, ignoring interactions among sectors and their combined impacts on the coastal and marine ecosystems, has placed at risk the heritage, livelihoods, and cultures of coastal communities that rely on healthy marine environments. ${ }^{21}$

$16 \quad$ Ibid.

17 Millennium Ecosystem Assessment, Marine and Coastal Ecosystems and Human Well-being: Synthesis (2005), available at <https://www.millenniumassessment.org/ documents/Document.799.aspx.pdf> accessed on 1 March 2018.

18 Ibid.

19 Ibid.

20 Akunga Momanyi, 'Governance and Institutional Frameworks' in UNEP and Nairobi Regional Convention Secretariat, Regional State of the Coast Report: Western Indian Ocean (2015).

21 Ibid. 
In 2010 Kenya adopted a new Constitutional architecture that places a premium on sustainable development as a key governance imperative and requires public participation in all processes. Based on this development, the present chapter assesses the extent to which Kenya's legal framework for management of wetlands in the coastal region adopts the ecosystem approach and whether it enhances the conservation and wise use of wetlands and thus aligns to the constitutional dictates of sustainable development. The main argument that the paper advances is that both in law and practice, the move towards ecosystem approach is slow and fledgling. The management approach is still characterised by sector specific focus, governance overlaps and legal gaps. However, the adoption of a 'green constitution'22 and the incorporation of the ecosystem approach in the National Environment Policy in 2014 provide a basis for sustainable management of wetlands in the Kenyan coast.

\section{Overview of the Kenyan Coast and Coastal Wetlands}

In Kenya, wetlands occupy between 3 to 4 per cent, or approximately 14,000 $\mathrm{km}^{2}$, of the land surface. ${ }^{23}$ Depending on climatic conditions that can sometimes extend to up to $6 \%$ of the land surface. ${ }^{24}$ Kenyan wetlands are diverse in type and distribution, although no national inventory of type, status and location currently exists. ${ }^{25}$ Importantly, some of the wetlands lie in coastal areas and it is these wetlands that are the focus of this chapter.

Kenya's coastline extends about $600 \mathrm{~km}$ along the seafront, from Somalia's border at Ishakani in the north (Longitude $1^{\circ} 41^{\prime} S$ ), to Tanzania's border at Vanga in the south (Longitude $4^{\circ} 40^{\prime} \mathrm{S}$ ). ${ }^{26}$ The Kenyan coastal environment is a site of rich biodiversity with high ecological and socio-economic value. ${ }^{27}$

22 Donald W. Kaniaru, 'Environmental Courts and Tribunals: The Case of Kenya (2011-2012) 29 Pace Environmental Law Review 566.

23 Kenya Land Alliance, Wise or Unwise Use: A Survey of Some Wetlands in Kenya (2006), unpublished report, on file with author.

24 Ibid.

25 For a discussion of wetlands in Kenya see generally, GW Howard, Wetlands of Kenya: Proceedings of a Seminar on Wetlands of Kenya (IUCN, 1992).

26 NEMA, State of the Coast Report: Towards Integrated Management of Coastal and Marine Resources in Kenya (Nairobi, 2009), available at <http://web.unep.org/nairobiconvention/ sites/unep.org.nairobiconvention/files/kenya_state_of_coast_report_final.pdf> accessed on 5 February 2018.

27 Ibid.; Republic of Kenya, Integrated Coastal Zone Management Policy (2013), adopted by the National Assembly on 3rd December, 2015. Available at <http://www.environment 
The main resources include land, rivers, lakes, estuaries and other wetlands, grasslands, coastal and mangrove forests, sea grass and coral reefs. These resources are useful to local communities acting as a source of livelihood. In addition, they support the coastal and national economy. They provide important goods and services, performing ecological and social functions. Kenya's Coast is also home to numerous threatened species.

The wetlands situated along the Kenyan coast are categorised as marine wetlands and include coastal lagoons, rocky shores and coral reefs. No mapping of wetlands has taken place in Kenya and there is, thus, no official information on the extent of wetlands within the coastal region. Discussions about wetlands along the Kenyan coast are normally intertwined with discussions on mangroves. Mangroves are tropical and sub-tropical woody trees or shrubs that occur naturally in brackish waters or estuarine wetlands in the intertidal zone. ${ }^{28}$ Kenya's mangrove forests and coastal wetlands are concentrated on the northern coast around the Lamu archipelago and the permanent Tana/ Sabaki River estuaries, with smaller wetlands occurring in the mouths of semiperennial and seasonal coastal rivers on the South Coast, at Shimoni-Vanga, Funzi and Gazi Bays, and Port-Reitz, Tudor, Mtwapa, Kilifi and Mida Creeks. ${ }^{29}$ There is no question that wetlands are one of the resources in the coastal area of Kenya. ${ }^{30}$ Consequently, the management of the coastal region directly impacts on the conservation and wise use of the wetlands that are situated there. Kenya is committed to managing the coastal zone, and the resources therein, in an integrated manner. Kenya's coastal wetlands are clearly a component of the resources to be managed sustainably using an integrated approach. As will be discussed in the following sections, this requires the existence of sound rules and institutions.

.go.ke/wp-content/uploads/2014/o1/Final-Draft-ICZM-Policy-revised-December-2013 .pdf $>$ accessed on 5 February 2018.

28 PB Tomlinson, The Botany of Mangroves (Cambridge University Press, 1986); PA Abuodha and JG Kairo 'Human Induced Stresses on Mangrove Swamps Along the Kenyan Coast' (2010) 458 Hydrobiologia $255^{-256}$. Available at <http://ro.uow.edu.au/scipapers/165/> accessed on 22 January 2018.

29 NEMA, State of the Coast Report (n 26) 9.

30 Ministry of Environment, Water and Natural Resources, Sessional Paper Number 13 of 2014 on Integrated Coastal Zone Management (2014). 


\section{Imperatives of the Ecosystem Approach}

The Convention of Biological Diversity, adopted by the international community in 1992, forms the basis for the ecosystem approach to management of the environment and natural resources. Prior to its adoption the prevailing approach was one of single species or habitat conservation. The CBD focusses on the conservation of biological diversity, which is defined as 'the variability among living organisms from all sources including, inter alia, terrestrial, marine and other aquatic ecosystems and the ecological complexes of which they are part; this includes diversity within species, between species and of ecosystem.' ${ }^{31}$ The two other foci of the Convention, in addition to the conservation of biological diversity, are the sustainable use of the components of biological diversity, and the fair and equitable sharing of benefits arising out of the utilisation of genetic resources. ${ }^{32}$

At the centre of conservation of biological diversity are conservation of species and of ecosystems. At the second meeting of the Conference of the Parties held in Jakarta, Indonesia in 1995, a decision was taken which brought to the fore the centrality of ecosystems and the ecosystem approach to the conservation of biodiversity. The decision provided a reaffirmation by the Conference of the Parties (COP):

that the conservation and sustainable use of biological diversity and its components should be addressed in a holistic manner, taking into account the three levels of biological diversity (these are genetic biodiversity, species diversity and ecosystems diversity) and fully considering socio-economic and cultural factors. However, the ecosystem approach should be the primary framework of action to be taken under the Convention. ${ }^{33}$

Although the decision clearly stipulated that the ecosystem approach would provide the guiding framework for the implementation of the $\mathrm{CBD}$, the Convention did not define the term. The only definition in the Convention is that of 'ecosystem'. An ecosystem is defined as 'a dynamic complex of plant, animal and micro-organism communities and their non-living environment interacting as a functional unit'. ${ }^{34}$ It was not until the fifth meeting of the cop held in

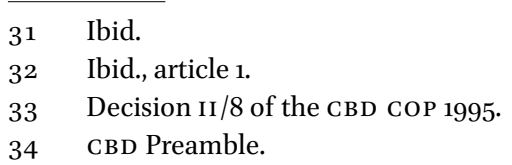


Nairobi in May, 2000 that the full meaning of the term 'ecosystem approach' was articulated and a definition adopted. A call was also made for its application and adoption in national policies and legislation. ${ }^{35}$

The definition adopted by the COP in 2000 defines the ecosystem approach as 'a strategy for the integrated management of land, water and living resources that promotes conservation and sustainable use in an equitable way'. ${ }^{36}$ It is an approach that seeks integration and coordination. Its aim is not to manipulate the ecosystem for the benefit of human beings just because human beings are part of the ecosystem. Rather, it seeks to manage human activities in the environment so as to ensure sustainability of the ecosystem. It does not ignore sectoral components or approaches to the management of the environment. Instead it seeks to harmonise them so as to encourage integration. As captured in the decision of the COP:

The ecosystem approach does not exclude other management and conservation approaches, such as biosphere reserves, protected areas, and single species conservation programmes, as well as other approaches carried out under existing national policy and legislative frameworks, but could, rather, integrate all these approaches and other methodologies to deal with complex situations. There is no single way to implement the ecosystem approach, as it depends on local, provincial, national, regional or global conditions. ${ }^{37}$

In addition to defining the 'ecosystem approach', the state parties adopted twelve principles to govern its implementation. These principles are complementary and interlinked, ${ }^{38}$ meaning that the achievement of the ecosystem approach to the conservation of biodiversity requires the adherence to all the twelve principles. The first principle provides that the objectives of the management of land, water and living resources are a matter of societal choices. ${ }^{39}$ Consequently, in managing biodiversity and specifically land, water and the living resources, context has to be taken into account. The views of different stakeholders have to be considered so that the management approach reflects the participation and perspectives of different groups in society. In addition,

35 Decision v/6, Conference of the Parties to CBD, Nairobi, 2000.

36 Ibid.

37 Ibid.

38 Ibid.

39 Ibid. Principle 1. 
both cultural and biological diversity are central components of the ecosystem approach, and management should take this into account. ${ }^{40}$

According to the second principle, management should be decentralised to the lowest level possible. ${ }^{41}$ Decentralisation is important in natural resource management as it enhances the levels of citizen's involvement and improves equity, efficiency and effectiveness in decision-making. It has been adopted in the management of various resources across the world in response to the failures of centralised and non-participatory approaches. It is an essential component of the ecosystem approach, since 'the closer management is to the ecosystem, the greater the responsibility, ownership, accountability, participation and use of local knowledge.42 This is particularly important in the context of the coastal wetlands as Kenya's Constitution introduced devolution in 2010, which is much deeper than decentralisation as it ensures that power and finances are transferred from the central government to lower level administrative authorities.

The third principle requires that managers of ecosystems consider the effect of their activities on other ecosystems, both those adjacent to the ecosystem being managed and others, even if they are not adjacent to it. ${ }^{43}$ This principle is predicated on the reality that the environment is an integrated whole and activities in relation to one part of it may impact on other components. It also buttresses the focus of integration which helps to realise sustainability in management of ecosystems.

The fourth principle notes that the ecosystem approach must be alive to and incorporate the economic context. This requires that the management approach is used to reduce those management distortions that adversely affect biological diversity, ${ }^{44}$ align incentives to promote biodiversity conservation and sustainable use, ${ }^{45}$ and internalise costs and benefits in the given ecosystem to the extent possible. ${ }^{46}$ The concept of externalities and internalities and its implications for land tenure and land use are best captured in the writings of Demsetz. For economists, the function of property rights is to internalize externalities. ${ }^{47}$ Demsetz provides the linkage between property rights

\begin{tabular}{ll}
\hline 40 & Ibid. \\
41 & Ibid. \\
42 & Ibid. \\
43 & Ibid. \\
44 & Ibid. \\
45 & Ibid. \\
46 & Ibid. \\
47 & For various perspectives on the definition of property rights from an economics perspec- \\
& tive and the function of property rights as an internaliser of externalities see generally
\end{tabular}


and externalities by arguing that property rights give one the right to benefit or harm oneself or another. ${ }^{48}$ It is the rules that inhere in property rights for determining how and whether one can benefit or be harmed that links property rights to externalities. ${ }^{49}$ Demsetz defines externalities as including external costs, external benefits, and pecuniary and non-pecuniary externalities. ${ }^{50}$ He then proceeds to point out that:

No harmful or beneficial effect is external to the world. Some person or persons always suffer or enjoy these effects. What converts a harmful or beneficial effect into an externality is that the cost of bringing the effect to bear on the decisions of one or more of the interacting persons is too high to make it worthwhile ... Internalizing such effects refers to a process, usually a change in property rights, that enables these effects to bear (in greater degree) on all interacting persons. ${ }^{51}$

For property rights to exist and be meaningful, according to the economic conception, the cost of internalization must be less than the benefit to be derived therefrom. This makes it economical for those affected by the costs and benefits to internalize them. This economic conception argues that the best property system is that of private property for it internalizes both costs and benefits making it possible to protect property rights. ${ }^{52}$

Principle five holds that as part of the ecosystem approach, maintenance of ecosystem services as part of conservation of ecosystem structure and functioning must be a priority. Provision of ecosystem goods and services, as demonstrated by the Millennium Ecosystem Assessment Report, is an important aspect of functioning ecosystems. A functioning ecosystem must ensure that

Harold Demsetz, 'Toward a Theory of Property Rights' (1967) 57 American Economic Papers and Proceedings 347, asserting that 'an owner expects the community to prevent others from interfering with his actions, provided that these actions are not prohibited in the specifications of his rights'; Yoram Barzel, Economic Analysis of Property Rights 3 (2d ed. 1997) (defining property as 'the individual's ability, in expected terms, to consume the good (or the services of the asset) directly or to consume it indirectly through exchange'); Armen A. Alchian, Economic Forces At Work 127, 130 (1977) ('By a system of property rights I mean a method of assigning to particular the authority to select, for specific goods, any use from a non-prohibited class of uses.').

48 Demsetz (ibid).

49 Ibid.

$50 \quad$ Ibid., 348 .

51 Ibid.

52 Harold Demsetz, 'Toward a Theory of Property Rights II: The Competition Between Private and Collective Ownership' (2002) 31 Journal of Legal Studies 653. 
ecosystem goods and services are provided. Related to this is the sixth principle which articulates the need to manage the ecosystems within the limits of their functioning. This principle recognises that unless the limits of the ecosystem are maintained, the ecosystems will not be able to perform their functions. In considering the likelihood or ease of attaining the management objectives, attention should be given to the environmental conditions that limit natural productivity, ecosystem structure, functioning and diversity. The limits to ecosystem functioning may be affected to different degrees by temporary, unpredictable or artificially maintained conditions and, accordingly, management should be appropriately cautious. ${ }^{53}$

According to the seventh principle, the ecosystem approach should be undertaken at the appropriate spatial and temporal scale. ${ }^{54}$ Consequently the boundaries of the ecosystem for management purposes will be determined by those involved in the management process, including experts and local communities. The eighth principle requires that due to the varying temporal scales, a long-term approach should be adopted in the management of ecosystems. ${ }^{55}$ Principle nine is based on the recognition that change is inevitable. ${ }^{56}$ Consequently an adaptive management approach is called for in managing ecosystems.

Principle ten calls for an appropriate balance between and integration of conservation and use of biological diversity. ${ }^{57}$ Principle eleven, for its part, requires considerations of all forms of relevant information, including scientific and indigenous and local knowledge, innovations and practices. ${ }^{58}$ This Principle recognises the place of information in the success of management of ecosystems. Such knowledge is both scientific and indigenous knowledge from local communities, a recognition that local communities, their knowledge and management practices have to be integrated in the process of managing ecosystems. It is for this reason that principle twelve calls for the involvement of all relevant sectors of society. ${ }^{59}$

As the articulation of these principles makes clear, there are several key focus issues that must be addressed to ensure the success of the ecosystem approach. Fundamentally at the base of these requirements are the broadening of stakeholder engagement, an integrated and wider ecosystem or geographical focus,

$\begin{array}{ll}53 & \text { Decision v/6 of COP of CBD, Nairobi, } 2000 . \\ 54 & \text { Ibid. } \\ 55 & \text { Ibid. } \\ 56 & \text { Ibid. } \\ 57 & \text { Ibid. } \\ 5^{8} & \text { Ibid. } \\ 59 & \text { Ibid. }\end{array}$


avoiding single species or issue approaches, and continuous evaluation of the simultaneous pressures on ecosystems. These actions will all aid in adaptive and integrated management so as to guarantee the success of ecosystem approach to management. The application of this approach is critical in the effective management of wetlands in coastal zones, since wetlands are subject to tremendous pressure for conversion to other uses and coastal zones contain numerous ecosystems with complex governance challenges.

\section{$4 \quad$ Managing Wetlands: Critical Concepts}

The international framework for the management of wetlands is captured in the Ramsar Convention on Wetlands of International Importance especially as waterfowl habitat. ${ }^{60}$ The Ramsar Convention establishes the objectives, approach and institutional arrangements for the management of wetlands. It belongs to the categories of international treaties which did not adopt the then current approach of focusing on single species or habitat conservation rather than on the ecosystem conservation. The Ramsar Convention essentially adopted an ecosystem wide approach, focussing on conservation of wetlands as habitat for waterfowls. According to its preamble, the Convention was adopted in recognition of: 'the fundamental ecological functions of wetlands as regulators of water regimes and as habitats supporting a characteristic flora and fauna, especially waterfowl';61 the 'economic, cultural, scientific and recreational value'62 of the resource; and the desire to 'stem the progressive encroachment on and loss of wetlands. ${ }^{63}$ This is underscored in the double objectives of the Convention which focus on preventing the encroachment and loss of wetlands and on promoting their conservation.

There are two important imperatives within the Ramsar Convention; conservation, on the one hand, and wise use, on the other. To ensure that these two imperatives are achieved, contracting parties to the Convention are under several obligations. First, each contracting party is required to designate at least one wetland on the List of Wetlands of International Importance (referred to simply as 'the List') ${ }^{64}$ This provides the springboard for all

6o Convention on wetlands of international importance especially as waterfowl habitat (entered in force on Dec. 21 1975) 996 U.N.T.S. 245 (1976) 11 ILM 97.

61 Ibid., preamble.

62 Ibid.

63 Ibid.

64 Ibid. Article 2(1). 
the other obligations that parties have as signatories to the Convention. The Convention does not provide details as to how a wetland qualifies to be considered as one of international importance and thus eligible to be placed on the List. Article 2 merely states that contracting parties are to designate 'suitable wetlands', and further, that once designated, 'the boundaries of each wetland shall be precisely described and also delimited on a map and (...) may incorporate riparian and coastal zones adjacent to the wetlands, and islands or bodies of marine water deeper than six metres at low tide lying within wetlands, especially where these have importance as waterfowl habitat'.65 Thus, being a waterfowl habitat is the first criteria for determining importance. In addition, to be placed on the List consideration should be made of the international significance of the wetlands based on ecology, botany, zoology, limnology and hydrology. ${ }^{66}$ Selection criteria for designating wetlands of international importance were originally adopted at the International Conference on Conservation of Wetlands and Waterfowl in Heiligenhafen in 1974 and have been refined by meetings of the Conference of the Parties (COP) since then. ${ }^{67}$

At the fourth meeting of the COP, detailed rules for identifying wetlands of international importance were adopted. ${ }^{68}$ These rules provide that a wetland will be considered to be of international importance if it meets one out of the three agreed criteria, namely:

- Representativeness of natural or near natural wetlands in the biogeographical region: play a substantial hydrological, biological or ecological role in the natural functioning of a major river basin or coastal system, especially where it is located in a trans-border position; or is an example of a specific type of wetland, rare or unusual in the appropriate biogeographical region.

- General criteria based on plants or animal: if it supports an appreciable assemblage of rare, vulnerable or endangered species or subspecies of plant or animal, or an appreciable number of individuals of any one or more of these species; or it is of special value for maintaining the genetic and ecological diversity of a region because of the quality and peculiarities of its flora and fauna; or it is of special value as the habitat of plants or animals at a critical stage of their biological cycle; or it is of special value for one or more endemic plant or animal species or communities.

65 Ibid.

66 Ibid. Article 2(3).

67 Mathews ( $\left.\mathrm{n}_{5}\right)$.

68 See <http://archive.ramsar.org/pdf/rec/key_rec_4.o2e.pdf> accessed on 25 March 2018. 
- Criteria based on Waterfowl: if it regularly supports 20,000 waterfowl; or it regularly supports substantial numbers of individuals from particular groups of waterfowl, indicative of wetland values, productivity or diversity; or where data on populations are available, it regularly supports $1 \%$ of the individuals in a population of one species or subspecies of waterfowl. 69

Two interesting provisions are contained in Article 2 relating to the designation of wetlands onto the List of International Importance. The first relates to the sovereignty of states. The Convention points out that 'the inclusion of a wetland in the List does not prejudice the exclusive sovereign rights of the Contracting Party in whose territory the wetland is situated. ${ }^{70}$ The Convention thus preserves the states' sovereign rights over their territory and over the management of the wetlands in their territory. Secondly, on designating wetlands onto the List, states are to consider their international responsibilities for the conservation, management and wise use of migratory stocks of waterfowl. ${ }^{71}$

The second obligation that parties to the Ramsar Convention have revolves around the obligation to promote conservation and wise use of wetlands. The Convention obliges contracting parties to 'formulate and implement their planning so as to promote the conservation of the wetlands included in the List, and as far as possible the wise use of wetlands in their territory.72

The third obligation is the requirement to 'promote the conservation of wetlands and waterfowl by establishing nature reserves on wetlands whether they are included on the List or not, and provide for their wardening. ${ }^{73}$ To enable the parties to fulfill their obligations, the Convention encourages research and the exchange of data and publications,${ }^{74}$ promotion of training of personnel in the area of wetland research, management and wardening. ${ }^{75}$ The Convention recognizes the international nature and importance of wetlands and calls for co-operation between contracting parties and consultation in the implementation of obligations under the Convention. ${ }^{76}$

The implementation of the Ramsar Convention depends on the good will of the members and their voluntary adherence to the resolutions and recommendations of the COP. There are no sanction mechanisms or financial arrangements within the text of the Convention.

$\begin{array}{ll}69 & \text { Ibid. } \\ 70 & \text { Ramsar (n 6o) Article 2(3). } \\ 71 & \text { Ibid. Article 2(6). } \\ 72 & \text { Ibid. Article 3(1). } \\ 73 & \text { Ibid. Article 4(1). } \\ 74 & \text { Ibid. Article 4(3). } \\ 75 & \text { Ibid. Article 4(5). } \\ 76 & \text { Ibid. Article 5(1). }\end{array}$


At the center of protecting wetlands are the concepts of 'conservation' and 'wise use'. The term conservation is very central to the discourse on wetlands management. Indeed, the Ramsar Convention provides that it is one of the two tasks to be undertaken in the process of sustainable management of wetlands, the other being wise use. In everyday usage, the term conservation is used interchangeably with that of preservation. However, the two terms differ tremendously in environmental language. Preservation refers to the maintenance of environment and natural resources in their natural state without any interference whatsoever. This concept used to be the dominant approach in the early stages of environmental management. However, it is now only applied to limited types of natural resources, such as unique biological formations, endangered or threatened species, representative biomass or other natural resources and cultural sites of importance. It requires adopting a hands-off policy in the management of natural resources in order to maintain the characteristics of these resources. ${ }^{77}$ Conservation, on the other hand, refers to the sustainable use of renewable resources and the avoidance of waste of non-renewable resources. In other words, conservation as a mode of management, refers to components of the environment such as fisheries, forestry and land, which are renewable and should be used in such a way as to protect the threshold of sustainability. ${ }^{78}$ For non-renewable resources such as minerals, petroleum and oil, the meaning of conservation is to utilize the resources so as to avoid waste and thus protect the interests of future generations to the greatest extent possible. In other words, even diamonds might not be forever, if users are wasteful. ${ }^{79}$ Conservation is therefore the linchpin for sustainable utilization of the environment and its component natural resources and for the promotion of sustainable development.

The second and by far the most unique concept relating to wetlands is that of 'wise use'. The Ramsar Convention requires contracting parties to 'formulate and implement their planning so as to promote the conservation of Wetlands included in the List, and as far as possible the wise use of wetlands in their territory' ${ }^{80}$ The term wise use was, however, not defined by the Ramsar Convention. The first attempt to define 'wise use' was made at the 3 rd meeting of the cop held in Regina, Canada in 1987. At this meeting, guidelines

77 Charles O Okidi, 'Concept, Structure and Function of Environmental Law' in CO Okdi and others (eds), Environmental Governance in Kenya: Implementing the Framework Law (EAEP, 2008) 3-6o.

78 Ibid.

79 Ibid., 5 .

8o Ramsar Article 3(1). 
on the Wise Use of Wetlands were adopted. ${ }^{81}$ The issue was further addressed at the 4th COP in Montreux, Switzerland in 1990. At this meeting, guidelines for the implementation of the wise use concept were adopted. ${ }^{82}$ Additional guidelines for the implementation of the wise use concept were adopted at the next COP in Kushiro in $1993 .{ }^{83}$

The Wise Use Guidelines ${ }^{84}$ define the term 'wise use' to mean 'sustainable use of wetlands for the benefit of mankind in a way that is compatible with maintaining the natural properties of the ecosystem'. The guidelines outline the need for national action to improve institutional and organizational arrangements; address legislative and policy needs; increase knowledge and awareness of wetlands values; inventory and monitor the status of wetlands; and identify programme priorities and develop action plans for specific sites as components of a national wetland policy. More recently the definition of the term 'wise use' has been refined to mean 'the maintenance of their ecological character, achieved through the implementation of ecosystem approaches, within the context of sustainable development' ${ }^{\prime 5}$ This definition links wise use to the ecosystem approach. It focusses on a determination of trade-offs in the use to which wetlands will be put so that a balance is achieved between the nature of any proposed exploitation and the benefits that will accrue to the wetland versus any impacts or disadvantages (such as degradation of ecosystem components, processes and loss of other services provided by the wetland).

To ensure wise use of wetlands, it is imperative that their diverse uses be realized and captured in planning processes. The diverse goods and services available and supplied by wetlands' ecosystems need to be captured in determining the value of wetlands. The legal framework can and should help this process, so as to eradicate the practice of converting wetlands to what is conveniently seen in most jurisdictions as more productive uses. As a result, the value of wetlands is consistently underestimated and their importance overlooked,

$81 \quad$ Annex to Recommendation 3.3 (Regina, Ramsar CoP, 1987).

82 Annex to Recommendation 4.10 (Montreux, Ramsar, COP, 1990).

83 Annex to Resolution 5.6 (Kushiro, Ramsar, COP, 1993).

84 The Wise Use Guidelines are available at < https://www.ramsar.org/sites/default/files/ documents/library/key_rec_4.10e.pdf $>$ accessed on 6 May 2018.

85 This definition was adopted at the 9th Conference of the Parties of the Ramsar Convention as Resolution IX.1 Annex A, $2005<$ http://archive.ramsar.org/cda/en/ramsar -documents-resol-resolution-ix-1-annex-a/main/ramsar/1-31-107\%5E23536_40oo_o_> accessed on 5 May 2007; Ramsar Convention Secretariat, Wise use of wetlands: A Conceptual Framework for the Wise use of wetlands, Ramsar handbooks for the wise use of wetlands, 3rd edition, vol 1 (Ramsar Convention Secretariat, Gland, Switzerland, 2007). 
and ultimately it is the rural poor who lose out. ${ }^{86}$ To ensure a movement away from the simplistic valuation methods of wetlands, the valuation process and system should appreciate the diverse values of wetlands and capture these. This way, decisions on wetlands will be based on all the goods and services that wetlands provide to the society. ${ }^{87}$

While the Ramsar Convention's principal focus is on Wetlands which have been designated as being of international importance by being placed on the Ramsar list, its provisions are important for managing wetlands globally.

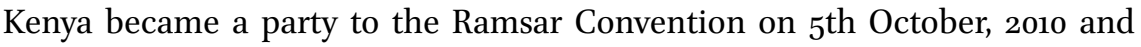
has since then designated six sites to the list, with Tana River Delta, situated in the Kenyan coast being the latest site to be designated. This wetland is also the most important in the Kenyan coast and has been subjected to tremendous pressures for conversion to aquaculture and agriculture..$^{88}$

The Ramsar Convention has also informed significant action within the country on managing wetlands. Attempts have been made to align the legislative and policy framework with the provisions of the Convention which require Kenya, as part of meeting its obligation under the Convention, to develop sound policy, legislative and institutional structures so as to ensure conservation and wise use of wetlands generally, and not just the ones on the Ramsar Lists.

The Ramsar Convention's focus on an ecosystem wide approach to management of the environment and resources therein and its call for wise use of wetlands align to the principles of the ecosystem approach discussed in this chapter. As a party to both the CBD and the Ramsar Convention, Kenya is thus

86 BD Ratner and others, Undervalued and Overlooked: Sustaining Rural Livelihoods through Better Governance of Wetlands (WorldFish Centre Studies and Reviews No 28, 2004) 1.

87 For a discussion on the concept of valuation of wetlands goods and services, see generally L. Emerton, Value and Rewards: Counting and Capturing Ecosystem Water Services for Sustainable Development (IUCN Nature and Economics Technical Paper, NO 1, IUCN The World Conservation Union, Ecosystems and Livelihood Group, Asia, Colombo, 2005); L Emerton, 'The Economic Value of Africa's Wetlands' in ML Thieme and others, Freshwater Ecoregions of Africa and Madagascar: A Conservation Assessment (WWF, 2005); EB Barbier, Economic Valuation of Wetlands (Ramsar Convention Bureau, Gland, 1997); L Emerton, Economic Tools for Valuing Wetlands in Eastern Africa (IUCN Eastern Africa, 1998).

88 Siri Eriksen and others, 'Land Tenure and Wildlife Management' in Calestous Juma and JB Ojwang (eds), In Land We Trust: Environment, Private Property and Constitutional Development (Initiative Publishers and Zen Books 1996) 199-230. See also Collins Odote, Regulating Property Rights to Ensure Sustainable Management of Wetlands in Kenya, unpublished $\mathrm{PhD}$ Thesis, University of Nairobi, 2010 (on file with author). 
under an international obligation to adopt the ecosystem approach in managing its wetlands. Wetlands in Kenya

In discussing the ecosystem approach within the context of management of Kenyan wetlands, a review of the enabling legal and policy framework is apt. Within Kenya, there is no single piece of legislation that either deals with wetlands generally, the Kenyan coast, or wetlands within the Kenyan coast. The relevant laws and policy provisions must consequently be gleaned from those that govern both the Kenyan coast and wetlands more broadly.

The overall framework for environmental management is the Kenyan Constitution. The Kenyan Constitution has an environmental focus, recognizing in its preamble 'the environment as (...) heritage' 89 of the people of Kenya and is determined to 'sustain it for future generations'. ${ }^{90}$ It then includes detailed provisions for environmental management, including the recognition and protection of the right to a clean and healthy environment ${ }^{91}$ and responsibility for protection of the environment so as to ensure the realization of that constitutional right. ${ }^{92}$ Although the Constitution does not mention wetlands specifically, it provides the overall context for their management. In Article 10, the Constitution provides that the principle of sustainable development is key to all governance and management processes in the country. Management of wetlands in Kenya is a governance function which falls within the purview of Article 10. Consequently, the policies, laws and practices that Kenya adopts in managing its wetlands at the coast must respect and promote sustainability.

Although the Constitution does not elaborate on the legal content of sustainable development, this task has been undertaken at the international level. The Brundtland Commission report simply but powerfully defined the concept as 'development that meets the needs of the present generation without compromising the abilities of future generations to meet their own needs, ${ }^{93}$ while Judge Weeramantry, in acknowledging the importance of the concept, argued that 'after the early formulations of the concept of sustainable development,

89 Constitution of Kenya, 2010, Preamble.

9o Ibid.

91 Article 42, Constitution of Kenya, 2010.

92 Article 69, Laws of Kenya.

93 The Report of the World Commission on Environment and Development (WCED), Our Common Future (Oxford University Press, 1987). 
it has been recognized that development cannot be pursued to such a point as to result in substantial damage to the environment within which it is to occur. Therefore development can only be pursued in harmony with the reasonable demands of environmental protection. ${ }^{94}$ In 2015 , the international community gave a full iteration of the content of sustainable development by adopting the Sustainable Development Goals, a set of 17 goals and 169 targets. ${ }^{95}$ SDG 14 focusses on life below water, with a view to conserving and sustainably using the oceans, seas and marine resources for sustainable development. ${ }^{96}$ Thus sustainable development provides a framework for managing land and water resources. Its inclusion in the Kenyan Constitution provides a framework for governing wetland resources. In addition, the Constitution includes marine areas both in the context of marine navigation ${ }^{97}$ and also as part of marine lands within the definition of land. ${ }^{98}$

The main legislation for managing wetlands remains the Environmental Management and Coordination Act (EMCA). ${ }^{99}$ Section 42 of the EMCA provides for the protection of wetlands, by prohibiting certain activities, including draining, depositing substances, introduction of alien species, excavation or erection of structures on a wetland without prior approval of the National Environment Management Authority. ${ }^{100}$ The approval to be granted, must be preceded by an environmental impact assessment, ${ }^{101}$ which details possible negative effects of the envisaged activity on the wetlands and the necessary mitigation measures to ensure that the activity does not compromise the status and quality of the wetland ecosystem. Further, under the Act, the Minister has issued detailed guidelines for the management of wetlands, which are currently under review.

The EMCA also focusses on the conservation of coastal zones, ${ }^{102}$ providing for the declaration by the cabinet secretary of any area as a coastal zone, ${ }^{103}$ and preparation of an Integrated Coastal Zone Management (ICZM) Plan. ${ }^{104}$ The Act defines a coastal zone as a 'geomorphologic area where the land interacts with the sea comprising terrestrial and marine areas made up of biotic and

\footnotetext{
94 GabCikovo-Nagymaros Project (Hungary/Slovakia) (Judgment) [1997] ICJ Reports 7.

95 See $<$ https://sustainabledevelopment.un.org/?menu=1300 $>$ accessed on 1 February 2018.

96 <https://sustainabledevelopment.un.org/sdg14> accessed on 1 February 2018.

97 4th Schedule, Constitution of Kenya, 2010.

98 Article 26o, Constitution of Kenya, 2010.

99 Act Number 8 of 1999 .

100 Section 42, EMCA.

101 Ibid.

102 Section 55, EMCA.

103 Section 55(1), EMCA.

104 Section 55(2), EMCA.
} 
abiotic components or systems coexisting and interacting with each other and with socio-economic activities'.105 The development of an ICZM Plan is a recognition that the coastal zone should be managed as a single unit with the rules and institutions for dealing with its various components aligned and coordinated to ensure harmony and promote sustainability.

In 2014, the Government of Kenya developed an ICZM Policy. ${ }^{106}$ The Policy provides the basis for the application of the ecosystem approach in the management of the coastal zone and by implication wetlands as a resource found in the coastal zone. The objectives of the Policy demonstrate the relevance of the ecosystem concept to management of the entire coastal zone and the resources in it. The overall objective of the Policy is to guide the management and utilization of the coastal and marine environment and its resources to ensure sustainable livelihoods and development. ${ }^{107}$ To achieve this, the Policy specifically focusses on: promoting integrated planning and coordination of coastal developments across the various sectors; promoting sustainable economic development to secure livelihoods of coastal communities; conserving the coastal and marine resources and environment for sustainable development; managing environmental risks associated with changes in shoreline and climate; developing capacity in research and education and enhancing stakeholder awareness and participation in sustainable resource management; and establishing effective institutional and legal frameworks for implementation of the ICZM policy. ${ }^{108}$ The Policy recognizes that the ecosystem approach will guide the process of realizing these objectives, providing that the ecosystem approach 'recognizes the relationships and inter-linkages between all components of the wider ecosystem in addressing coastal zone management issues'.109 Consequently, when applying the ecosystem concept to managing wetlands in the coastal zone, it has to be recognized that wetlands are just one of the ecosystems found along the Kenya coast and that they cannot be conserved in isolation from the wider coastal zone. In addition, and as required by the ecosystem approach, successful conservation of wetlands requires a focus on wetlands throughout the country and not just those located along the coast. As the ICZM Policy underscores, the ecosystem approach is 'critical in effectively addressing issues affecting ecosystems that stretch beyond the coastal zone

\footnotetext{
105 Section 2, EMCA.

106 Republic of Kenya, Sessional Paper Number 13 of 2014 on Integrated Coastal Zone Management (ICZM) Policy, 2014.

107 Ibid.

108 Ibid.

109 Ibid.
} 
administrative area."10 Moreover, the Policy underscores that 'the ecosystem approach will be applied in the management of the resources as some of the pressures affecting the coastal environment are external to the coastal zone such as river catchment area.'111 This is, however, using the ecosystem as a habitat and not as a management approach.

The development of the ICZM Policy had been required by the EMCA. The first State of the Coast report developed in 2009 also reinforced the importance of an integrated approach to the management of Kenya's coastal marine resources. Importantly, the Policy recognizes as part of the guiding principles the 'use of ecosystem-based approach that recognizes the relationships and inter-linkages between all components of the wider ecosystem in addressing coastal zone management issues.'112

The greatest policy recognition for the ecosystem approach to management is, however, contained in the National Environment Policy (NEP). ${ }^{113}$ The NEP was developed so as to provide a holistic and coordinated policy framework for managing Kenya's environment and biodiversity. A key focus of the NEP is the management of ecosystems and sustainable use of natural resources. It stipulates that:

Ecosystems provide a wide range of goods and services. These include provisioning, regulating, cultural and supporting services. Despite the services they provide, ecosystems are under pressure from human activities. The most critical ecosystems in Kenya include forests, freshwaters, wetlands, coastal and marine, mountains, arid, semi-arid and spectacularly diverse wildlife populations. ${ }^{114}$

On marine ecosystems, the NEP identifies the key threats they face, which include pollution from land-based activities and other sources. ${ }^{115}$ Consequently several policy measures are proposed, including development of an integrated coastal zone management policy, coordinating the role of various agencies with management responsibility at the coast, and empowering local communities. In addition, the NEP recognizes the ecosystem approach to management as an important tool for environmental management. Indeed, one of the guiding principles underpinning the NEP is the ecosystem approach to management,

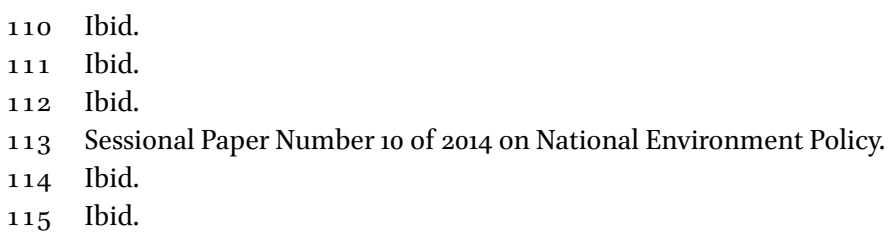


with the policy committing that 'an integrated ecosystem approach to conserving environmental resources will be adopted and enhanced to ensure that all ecosystems are managed in an integrated manner while also providing a range of benefits to the citizenry'116

Given this legal and policy framework, it is evident that Kenya recognizes the ecosystem approach and its application to the management of coastal resources, including wetlands. However, its successful application is dependent on the successful implementation of the legal regime and the practical arrangements for the conservation and wise use of wetlands in Kenya and, in particular, along the Kenyan coast.

Adhering to the requirements of the Ramsar Convention, which calls for wise use of wetlands, requires an appreciation of the multiple functions of wetlands and their linkages to other ecosystems. Wetlands that exist along the Kenyan coast must be used within the overall conservation focus for coastal zones. The ICZM Policy provides guidance and calls for an integrated approach, one that recognise that coastal zones are subject to multiple uses. However, despite this recognition in law and policy, there are numerous challenges to adhering to the requirement for wise use of wetlands. A fundamental reason for the inability to wisely use wetlands arises from the failure to apply the ecosystem approach to management.

Pressures from developmental and agricultural activities are a main obstacle to the wise use of wetlands. Due to the limited amount of land available for agricultural purposes and the prevailing view of wetlands as land not suited for any purposes, there are always pressures to convert them to development purposes without considering their environmental benefits and without regard to the importance of wise use. In the Tana Delta, for example, the wetland has suffered from pressures from coastal aquaculture aimed at shrimp farming in the delta, as well as pressures from the Mumias Sugar Company Tana and Athi River Development Authority (TARDA) promoting the undertaking of sugarcane farming. More recently, the Government has decided to grant several acres of land to the Qatar government upon which to undertake commercial farming, despite the richness of the biodiversity within the wetlands and their use as a grazing area and source of water for local communities. These decisions did not take into account the concept of wise use.

116 Ibid. 
Other challenges facing wetlands in coastal zones relate to the extent of the coastal zone in Kenya and the inextricable relationship between marine areas below low water mark, the area between the low water mark and the highwater mark, and the zone immediately above the high-water mark. The Draft ICZM Policy provides that the coastal zone consists of a closely connected terrestrial and marine environment. In Kenya, the marine environment comprises water, beach and the highest water mark ever recorded. The question remains, however, where the highest water mark (generally referred to as the Mean High-Water Spring) lies. The Survey Act ${ }^{117}$ provides some guidance. Rule 110 of the Survey Act deals with this issue by providing that 'Where unalienated Government land fronting on the area of the coast is being surveyed for alienation, a strip of land not less than 60 metres in width shall normally be reserved above high-water mark for Government purposes.'118 This would mean that the extent of the highest water mark of the Mean High-Water Spring is 60 metres.

The above issue was the subject of legal proceedings in the case Sea Star Malindi Ltd v. Kenya Wildlife Service ${ }^{119}$ where the Kenya Wildlife Service (Kws) sought to restrain a landowner in Malindi town from constructing a hotel on the land based on the argument that they intended to extend a marine park to the disputed area. The Kws asked the landowner not to effect any construction within 100 feet from the high-water mark. The matter went to court where the High Court held that the land in question belonged to the plaintiff and that the Kws had not presented evidence to justify their claim to the 100 feet in their letter. In the words of the court:

if the respondent was of the opinion that the suit land being contiguous to marine park, activities on it such as constructing septic tank might seriously interfere with the ecosystem in the area, all it needed to do was convince the Minister concerned to have the land acquired with the consent of the owner who was the competent authority or by way of Land Acquisition Act. Having so acquired the land the Minister would declare it a marine park or national park and then proceed to have the conservation of the area. ${ }^{120}$

This decision correctly adjudged that 100 feet was unknown to Kenyan law. However, there is a buffer zone which is 60 feet as contained in the Survey Act.

\footnotetext{
117 Chapter 299, Laws of Kenya.

118 Ibid.

119 KLR 1 (E\&L) 512.

120 Ibid., 513.
} 
Further, there are provisions specific to wetlands conservation in coastal and marine areas. Rule 114 of the Survey Regulations, for example, stipulates as follows as regards to wetlands:

(1) Where an area fronts a swamp, a give-and-take straight line boundary shall be adopted whenever possible,

(2) Indefinite median lines, which cannot be re-established by survey, shall be avoided,

(3) Swamps of an average width of 150 metres or more shall be excluded from the farms, and a straight boundary along the edge of the swamp shall be surveyed and beaconed.

Thus, while there is recognition of the need to protect the coastal environment, there continues to be 'uncertainty in the delimitation of what constitutes the coastal zone, including coastal wetlands or swamps.'121

Another key challenge relates to pollution. Pollution of the sea and coastal areas derives from both land-based and water-based sources. The national legal framework seeking to address these pollution sources on-land and onsea is woefully inadequate, with most ocean-based pollution being dealt with mainly by international law. Nevertheless, a critical tool to deal with pollution relates to the regulation of land use. The Kenyan Constitution contains provisions granting the state police powers over all land in Kenya, which power is to be exercised for several reasons, including land use planning. ${ }^{122}$

Land use planning is a critical tool as it provides for regulating competing land uses and ensuring that those uses are sustainably undertaken. However, in the context of wetlands in the coastal zone several challenges arise. First, there is contestation as to whether the appropriate approach to regulating the use of wetlands is through the tool of development control, hence land use planning, or through compulsory acquisition as suggested by the High Court in the Star Malindi case above. This contestation revolves around the concepts of prohibition on conveyance versus conveyance with prohibition.

At its heart, the debate revolves around whether the better approach is one which focuses on prohibiting the conveyance of wetlands. Under this approach, wetlands will be excluded from conveyance even if they appear on private land as they will be excluded from the property of individuals. The second option is to allow conveyance but to place prohibitions or limitations on the sale such that wetlands will be viewed as public goods with their use being

121 CO Okidi, 'Legal Aspects of Management of Coastal and Marine Environment in Kenya' in CO Okidi and others (eds), Environmental Governance in Kenya: Implementing the Framework Law (Oxford University Press, 2008) 440, 443.

122 Article 66, Constitution of Kenya. 
regulated, rather than their transfer being prohibited. This means that conveyance will be allowed, but there will be conditions or prohibitions placed on the conveyance.

In the final analysis, it is submitted that both approaches should be adopted. For some wetlands, based on their fragility and sensitivity, no conveyance should be allowed. Rather, they should be designated as critical ecosystems and their conveyance prohibited. For the rest of the wetlands, legislation should provide that their transfer has conditions attached to it. Such conditions should be geared towards maintaining the integrity of the wetlands' ecosystems and promoting wise and sustainable use of the wetland and its component resources.

Even if the issue of their conveyance is settled, however, one limitation of relying on land use planning law arises from the non-inclusion of sea-based planning as part of Kenya's land use laws. Wetlands transcend both the land and water space, extending into the sea. The limits of the traditional doctrine of land use planning have led to the evolution of the concept of marine spatial planning (MSP) as a tool to balance competing uses within the marine ecosystem and avoid user-conflicts. ${ }^{123}$ MSP is the latest innovation in the planning framework that started with the development of land use planning. ${ }^{124}$ MSP has been gaining traction in environmental policy debates and in emerging state practice as an effective tool for adaptive and multi-scale management, providing mechanisms for the resolution of jurisdictional conflicts between actors in the marine environment. ${ }^{125}$ It is 'a public process of analyzing and allocating the spatial and temporal distribution of human activities in marine areas to achieve ecological, economic, and social objectives that are usually specified through a political process'.126 It is consequently a 'strategic, forwardlooking, planning tool for regulating, managing, and protecting the environment, including through the allocation of space, that addresses the multiple, cumulative and potentially conflicting uses of the sea.'127

123 F Maes, 'The International Legal Framework for Marine Spatial Planning' (2008) 32 Marine Policy 797; M George and others, 'Marine Spatial Planning: What Does it Have to Offer Malaysia?' (2016) 31 The International Journal of Marine and Coastal Law 242.

124 HD Smith and others, 'The Integration of Land and Marine Spatial Planning' (2011) 15 Journal of Coastal Conservation 291, 291.

125 M George and others ( $\mathrm{n}$ 123).

126 Unesco, Marine Spatial Planning:A Step by Step Approach Towards Ecosystem Based Management (2009) 18 available at <http://unesdoc.unesco.org/images/oo18/oo1865/186559e .pdf $>$ accessed on 20 March 2018.

127 MSsP Consortium (2006), Marine Spatial Planning Pilot. Final Report to Department of Environment, Food and Rural Affairs, UK. 
MSP supports the application of the ecosystem approach to management due to its focus on integration. Recognition and application of this concept in Kenya will help improve the conservation and wise use of coastal wetlands by ensuring that decisions on their use recognise the multiple functions of wetlands and balance the interests of competing users. It will also ensure that wetlands are dealt with not as isolated habitats but as part of the wider ecosystem within the coastal zone, one that is integrated and extends from the land all the way into the sea.

Towards Ecosystem Approach to Wetlands Management in Kenya: Concluding Ideas

It is important that Kenya fully implements the ecosystem approach in the management if its coastal and marine resources. Doing so will ensure that the wise use of wetlands is undertaken within a context that appreciates that wetlands are just one of the resources within the coast and that their use affects and is affected by what happens to other ecosystems and resources. An ecosystem approach allows for a holistic view and is better suited to achieving sustainability. Measures need to be put in place to apply the twelve principles adopted by the COP of the СBD to guide the application of the ecosystem approach.

In addition, the implementation of the ecosystem approach will require adaptive governance. This will require clear, linked and collaborative structures and processes aimed at avoiding overlaps and institutional rivalries. There is currently no single institution that is responsible for management of wetlands in Kenya. To improve their management, 'adoption of a policy framework, improvement of legal rules for its management and harmonisation of institutional structures for their regulation,' ${ }^{\prime 28}$ is necessary. Such an approach will seek to map out the role of the different agencies involved in managing the coastal zone and assigning responsibility for the coastal zone to the most appropriate agency, while ensuring that the relevant agency coordinates with other agencies addressing ecosystems connected to wetlands.

It is also important that the role of local communities in environmental management and their involvement be improved. This is a prerequisite of Kenya's constitutional architecture, which recognises and requires participatory governance in all undertakings. In the final analysis, the country's

128 C Odote, 'Wise Use and Sustainable Management of Wetlands in Kenya' in CO Okidi and others (eds), Environmental Governance in Kenya: Implementing the Framework Law (East African Educational Publishers, 2008) 335, 354. 
management approach must move away from the single species approach to one that is inclusive, integrated and adaptive. This is the essence of the ecosystem approach, the defining characteristics of which include being geographically specified, adaptive in development over time as new information becomes available or as circumstances change, taking into account ecosystem knowledge and uncertainties, recognizing that multiple simultaneous factors, including those external to the ecosystem, may influence the outcomes of management, and striving to balance diverse societal objectives that result from resource decision making and allocation. Additionally, because of its complexity and emphasis on stakeholder involvement, the process of its implementation needs to be incremental and collaborative. ${ }^{129}$

A move towards an ecosystem approach also needs to recognise the place of human beings in the success of conservation initiatives, provide a link between environmental management and political governance, pay attention to the new devolved governance arrangement, align planning processes and structures to the land and water linkages, and adapt to the new realities including the discoveries of extractives in Kenya. In the final analysis, Kenya's efforts must also focus on regional and global collaboration in recognition of the nature of the oceans as part of the global commons. The National Environmental Management Authority and the Kenya Wildlife Service are the two institutions that have hitherto played roles relevant to wetlands management. Even between them there is continued contestation as to which has the primary responsibility over wetlands. In the devolved structure of Kenya, the County Government, too, has responsibility over environment and by extension wetlands. An ecosystem approach will require that there is clear coordination of the functions of these bodies so as to avoid conflict and enhance collaboration.

Although the legal and policy framework for management of resources within the Kenyan coast recognises the ecosystem approach, the country is yet to ensure that the approach is fully appreciated and applied by all actors. Effective application and implementation of the ecosystem approach would help to ensure that Kenya's coastal resources are conserved and wisely used as required by the Ramsar Convention to which Kenya is a party. It would also ensure that Kenya is putting into practise the commitments it has made under the $\mathrm{CBD}$, to which it is also a party, that call for adoption and application of the ecosystem approach in the management of land, water and living resources, an issue that would be aptly demonstrated through wise use of wetlands in the Kenyan coast.

129 MP Sissenwine and SA Murawski, "Moving beyond "intelligent tinkering”: advancing an ecosystem approach to fisheries' (2004) Series 274 Marine Ecology Progress 291. 


\section{Bibliography}

\section{Books}

Tomlinson PB, The Botany of Mangroves (Cambridge University Press 1986).

\section{Official Publications}

Barbier EB, Economic Valuation of Wetlands (Ramsar Convention Bureau, 1997).

Emerton L, Economic Tools for Valuing Wetlands in Eastern Africa (IUCN Eastern Africa, 1998).

Emerton L, Value and Rewards: Counting and Capturing Ecosystem Water Services for Sustainable Development (IUCN Nature and Economics Technical Paper, NO 1, IUCN - The World Conservation Union, Ecosystems and Livelihood Group, 2005).

Mathews GVT, The Ramsar Convention on Wetlands: Its History and Development (Ramsar Convention Bureau, 1993).

Millennium Ecosystem Assessment, Ecosystems and Human Well-being: Synthesis (2005), available at <https://www.millenniumassessment.org/documents/ document.356.aspx.pdf> accessed on 24 March 2018.

Momanyi A, 'Governance and Institutional Frameworks' in UNEP and Nairobi Regional Convention Secretariat, Regional State of the Coast Report: Western Indian Ocean (2015).

MssP Consortium (2006), Marine Spatial Planning Pilot (Final Report to Department of Environment, Food and Rural Affairs, UK, 2006).

NEMA, State of the Coast Report: Towards Integrated Management of Coastal and Marine Resources in Kenya (Nairobi, 2009), available at <http://web.unep.org/ nairobiconvention/sites/unep.org.nairobiconvention/files/kenya_state_of_coast_ report_final.pdf> accessed on 5 February 2018.

Ramsar Convention Secretariat, Wise use of wetlands: A Conceptual Framework for the Wise use of wetlands, Ramsar handbooks for the wise use of wetlands, 3rd edition, vol 1 (Ramsar Convention Secretariat, Gland, Switzerland, 2007).

Ratner BD and others, Undervalued and Overlooked: Sustaining Rural Livelihoods Through Better Governance of Wetlands, World Fish Centre Studies and Review No 28 (World Fish Centre, 2004).

Republic of Kenya, Sessional Paper Number 10 of 2014 on National Environment Policy. Republic of Kenya, Sessional Paper Number 13 of 2014 on Integrated Coastal Zone Management (ICZM) Policy, 2014.

Shine C and de Klemm C, Water and the Law: Using Law to Advance Wetland Conservation and Wise Use (IUCN and Cambridge, 1999).

Unesco, Marine Spatial Planning: A Step by Step Approach Towards Ecosystem Based Management (2009) 18 available at <http://unesdoc.unesco.org/images/ 0018/001865/186559e.pdf $>$ accessed on 20 March 2018. 
World Commission on Environment and Development (WCED), Our Common Future (Oxford University Press, 1987).

World Resources Institute, Millennium Ecosystem Assessment: Ecosystems and Human Well-Being: Wetlands and Water, 2005. Available from <http://www.millennium assessment.org/documents/document.358.aspx.pdf> accessed 13 June 2016.

\section{Book Chapters}

Emerton L, 'The Economic Value of Africa's Wetlands' in ML Thieme (ed), Freshwater Ecoregions of Africa and Madagascar: A Conservation Assessment (World Wildlife Fund, 2005) 11.

Eriksen S and others, 'Land Tenure and Wildlife Management' in Juma C and Ojwang JB (eds), In Land We Trust: Environment, Private Property and Constitutional Development (Initiative Publishers and Zen Books 1996) 199.

Odote C, 'Wise Use and Sustainable Management of Wetlands in Kenya' in Okidi CO and others (eds), Environmental Governance in Kenya: Implementing the Framework Law (East African Educational Publishers, 2008) 335.

Okidi CO, 'Concept, Structure and Function of Environmental Law' in Okdi CO and others (eds), Environmental Governance in Kenya: Implementing the Framework Law (EAEP, 2008) 3 .

Okidi CO, 'Legal Aspects of Management of Coastal and Marine Environment in Kenya' in Okidi CO and others (eds), Environmental Governance in Kenya: Implementing the Framework Law (EAP, 2008) 440.

Okowa-Bennum P and Mwangi AM, 'Land Tenure and Forest Resource Management' in Juma C and Ojwang JB (eds), In Land We Trust: Environment, Private Property and Constitutional Development (Initiative Publishers and Zen Books 1996) 175 .

Situma FDP, 'Forestry Law and the Environment in Kenya' in CO Okidi and others (eds), Environmental Governance in Kenya: Implementing the Framework Law (East African Educational Publishers Ltd, Nairobi, 2008) 235.

\section{Journal Articles}

Abuodha PA and Kairo JG, 'Human Induced Stresses on Mangrove Swamps Along the Kenyan Coast' (2010) $45^{8}$ Hydrobiologia 255-256. Available at <http://ro.uow.edu .au/scipapers/165/> accessed on 22 January 2018.

Demsetz H, 'Toward a Theory of Property Rights II: The Competition Between Private and Collective Ownership' (2002) 31 Journal of Legal Studies 653.

Gardner RC, 'Banking on Entrepreneurs: Wetlands Mitigation Banking and Takings' (1996) 81 Iowa Law Review 529.

Gardner RC, 'Rehabilitating Nature: A Comparative Review of Legal mechanisms That encourage Wetland Restoration Efforts' (2003) 52(3) The Catholic University Law Review 573 . 
George M and others, 'Marine Spatial Planning: What Does it Have to Offer Malaysia?' (2016) 31 The International Journal of Marine and Coastal Law 242.

Kaniaru DW, 'Environmental Courts and Tribunals: The Case of Kenya (2011-2012) 29 Pace Environmental Law Review 566.

Maes F, 'The International Legal Framework for Marine Spatial Planning' (2008) 32 Marine Policy 797.

Sissenwine MP and Murawski SA, 'Moving beyond "intelligent tinkering”: advancing an ecosystem approach to fisheries' (2004) Series 274 Marine Ecology Progress 291.

Smith HD and others, 'The Integration of Land and Marine Spatial Planning' (2011) 15 Journal of Coastal Conservation 291.

\section{Other Print Sources}

Kenya Land Alliance, Wise or Unwise Use: A Survey of Some Wetlands in Kenya (2006), unpublished report.

Odote C, Regulating Property Rights to Ensure Sustainable Management of Wetlands in Kenya, unpublished PhD Thesis, University of Nairobi, 2010 (unpublished). 